\title{
THE CULTURE OF POVERTY IN PARIS ON THE EVE OF THE REVOLUTION
}

At the very beginning of the investigation, it is necessary to find a word to describe the European masses before the coming of the twin revolutions, the French and Industrial, that have contributed so much to the making of the modern world. "Proletariat" is clearly anachronistic; "wage-earners" is inadequate in a society where cash wages were far from being the most common form of payment for labor. "Working class" is too much identified with nineteenth century developments and, what is worse, conjures up an image of a homogeneous group that does not conform to eighteenth century realities. "Laboring poor" is by far the best, for it emphasizes two primary facts about the people with whom we are concerned: first, that, to one extent or another, they earned their living by doing manual labor, and, second, that they were being continuously impoverished, as Professor Labrousse has shown. ${ }^{1}$ The category has several virtues as a tool of historical analysis. It is large enough to take account of the complexities of eighteenth century social conditions, stressing the mobility and social intercourse that existed, albeit on a diminishing scale, between the master artisans and shopkeepers, their apprentices and journeymen on the one hand, and the domestics, beggars, criminals and floating elements in the population, on the other. Classes laborieuses and classes dangereuses lived side by side and recruited their personnel from one another. ${ }^{2}$ They did in fact form a whole, whom contemporaries called "les classes inférieures". If we look toward the future, we see that the French Revolu-

${ }^{1}$ C. E. Labrousse, La crise de l'économie française à la fin de l'ancien régime et au début de la Révolution (Paris, 1944).

2 Cf. for the nineteenth century, Louis Chevalier, Classes laborieuses et classes dangereuses (Paris, 1956). Although the present state of the research does not allow me to make a definitive statement on the matter, it is perhaps not too early to suggest that a good deal of what Professor Chevalier sees as novel in the 1830 s and 1840 s may have had important antecedents before the Revolution - notably the complex patterns of population exchange between city and country, and the inability of the Capital to absorb immigrants in any but a superficial way. 
tion was to bring about a temporary split in their ranks by politicizing those among them who became the sans-culottes, and that the Industrial Revolution was to complete this division on other bases by allowing some of the laboring poor to become petty capitalists, while forcing the majority to become proletarians or to fall further still into the netherworld of the lumpen-proletariat. In sum, the use of the concept of the laboring poor enables us to come close to the reality of eighteenth century Paris and to watch the disagregation of that reality with the passage of time.

What part of the population belonged to the laboring poor? On the basis of information found in marriage contracts, Furet estimates that in certain quarters, such as the Faubourg Saint Antoine, the figure may have been as high as 90 per cent in 1750-1755.' Léon Cahen counts 100,000 "salariés" in a population of approximately 550,000 at the same date. ${ }^{2}$ If a substantial part of these 100,000 are counted as heads of families, then we may conclude, however tentatively, that at least 50 per cent of the total urban population belonged to this category. ${ }^{3}$

For years historians tended to regard the activities of the laboring poor, and particularly of the sans-culottes during the Revolution, as the result of manipulation by their "social betters". It is only in relatively recent years that we have, by stages, come to recognize the often autonomous nature of their action. We have even so tried to explain that action in terms of response to the stimulus of bread shortages and

1 François Furet, "Pour une definition des classes inférieures à l'époque moderne", in: Annales: Economies, Sociétés, Civilisations, XVIII (1963), pp. 459-474.

${ }^{2}$ Léon Cahen, "La population parisienne au milieu du XVIIIe siècle", in: Revue de Paris, XVI, no. 17 (1 September 1919), pp. 146-170.

${ }^{3}$ It is not yet possible to give a quantitative breakdown of the constituent parts of the laboring poor. By this I mean not only the diverse socio-professional groups - butchers, bakers, candlestick makers - so dear to the hearts of French social historians. More important, in my view, is the need to distinguish between those exercising a trade within a guild framework and those outside the fold, between those who actually produced goods and those who engaged in marketing them, the petits marchands des rues. Furthermore, the social historian will want to study connections that may exist between place of origin and trade recruitment in and towards Paris, and the ways in which certain trades came to be dominated (and internally policed) by men of one province: given the lack of national integration in the eighteenth century, one might almost say: by men of one culture group as opposed to another. A concrete example: was it an accident that so many masons were recruited from the Limousin? The accent here must be on the heterogeneity of the laboring poor, and nothing that is said here, however much it attemps to establish characteristics shared by a large percentage of the total group, should be taken as questioning that fundamental fact. On the particular question of the floating population, see my article: "La Population flottante de Paris à la fin de l'ancien régime", in: Annales Historiques de la Révolution Française, No 187 (January-March, 1967), pp. 1-14. 
high prices, almost exclusively. This is not sufficient. While I have no doubt that the laboring poor believed with Brecht that one ought "first feed the face and then tell right from wrong," it is clear that we cannot allow the matter to rest there. Man does not live by bread alone, and lack of bread does not necessarily make a man a revolutionary. The entire experience of the eighteenth century bread riot bears witness to the fact. And even in 1789, we hear an unemployed and starving découpeuse en gaze (textile worker) say: "Le roi est bon; s'il savoit combien nous sommes malheureux, il ne nous laisseroit pas languir. .." She had six children, and her husband made 18 sous a day, for an annual wage of about 252 livres - assuming that he could find work at least 280 out of 365 days a year. In 1790, a year of more or less normal prices, the Comité de Mendicité of the Constituent Assembly estimated that a family of five needed a strict minimum of 435 livres a year in order to subsist. ${ }^{2}$ In other words, we have here a case of absolute indigence accompanied by protestations of loyalty to the monarchy and, by inference, to the established order. It is highly unlikely that this particular woman went out to storm the Bastille, but is it altogether possible that her next door neighbor did just that. But then what drives one man to revolution, while another man in similar circumstances remains passive, if bread no longer appears as the crucial variable? The answer must be derived from the study, first, of the material life of the poor, not only at moments of crisis but over a span of normal years, and, second, of the values peculiar to them. Although it is difficult to separate the two, it is with the latter that I would like to deal at this time.

I am convinced that a culture of poverty did in fact exist in eighteenth century cities, and that it consisted of a great deal more than getting drunk on gin or cheap wine. To be sure, this culture of poverty is not the same as that which has been brought to our attention by contemporary social scientists and commentators. ${ }^{3}$ Although the two cultures may have points in common, the very principle of historical specificity makes it impossible to read twentieth century observations back into our period. We cannot reason by analogy, and our task is made still more difficult by the limited amount of source material at our disposal,

1 Anon., Paris Aujourd'Hui, ou Idées diverses d'un citoyen du tiers état sur le commerce, l'opulence, et la pauvreté actuelle des habitans de cette ville (Paris, 1789), p. 11.

${ }^{2}$ Furet, loc. cit.

${ }^{3}$ See, for example, Oscar Lewis, "The Culture of Poverty", in: Scientific American, CCXI, no. 4 (October, 1966), pp. 19-25. I am much in Professor Lewis' debt for his stimulating work on this subject. 
given the tendency of the poor to be inarticulate. Still the potential results are such that a study of the culture of poverty is worth a try.

Commenting on a trip to Paris made in 1774, an English observer wrote:

"The French are really a contented race of mortals; - precluded almost from the possibility of adventure, the low Parisian leads a gentle, humble life, nor envies the greatness he can never obtain; but either wonders delightedly, or diverts himself philosophically with the sight of splendours which seldom fail to excite serious envy in a Englishman, and sometimes occasion even suicide, from disappointed hopes, which never could take root in the heart of these unaspiring people.... Emulation, ambition, avarice, however, must in all arbitrary governments be confined to the great; the other set of mortals, for there are none there of middling rank, live, as it should seem, like eunuchs in a seraglio; feel themselves irrevocably doomed to promote the pleasures of their superiors, nor even dream of fighting for enjoyments from which an irremediable boundary divides them. They see at the beginning of their lives how that life must necessarily end, and trot with a quiet, contented, and unaltered pace down their long, straight, and shaded avenue. ..."1

The avenue that led through life to an obscure grave was neither so long, nor so shaded from misfortune as Mrs. Piozzi indicates, but her observation is nonetheless substantially correct. The situation of the Paris poor was a static one. The channels of mobility were narrow and becoming more so as the century went on. A properly trained journeyman had less hope than ever before of becoming a master, while the unskilled new arrival from the country, come to make his fortune in the great city, was lucky to get even the lowest sort of menial work, and as often as not was forced to rely on public charity or to resort to beggary. There was no way out, and no place to hide.

To the misery imposed on the poor by their means of making a living was added the power of death, personally experienced on an every day basis in the eighteenth century - above all in the urban setting. ${ }^{2}$ Only a full scale study employing the methods of differential demography can tell the whole story. Here it is sufficient to note that in the years around 1770 infant mortality (before the age of one year) stood at 233 per thousand. In a group 1000 persons born in a given year,

${ }^{1}$ Hester Lynch Piozzi, Observations and Reflections made in the course of a Journey through France, Italy and Germany (London, 1789, two volumes), I, pp. 13-15.

${ }^{2}$ For an extended commentary on the power of death in the eighteenth century, see André Armengaud, Démographie et Sociétés (Paris, 1966). 
449 would be dead ten years later, and fewer than 300 would reach the age of 50 , which is to say that fewer than 300 would expect to see the birth of grandchildren. ${ }^{1}$ These figures given for France as a whole would most certainly be higher in the case of the urban poor. Is there any wonder then that they developed a sense of futility, that they lost whatever dynamism they may once have had - and I am thinking here in individual terms, of the young men who set out to make their way in the world only to be ground down by defeat into despair. Their attitude towards death itself is characterized mainly by acceptance. "Mourning and consternation" were indeed present, but death was implacable, and there was nothing to be done but to accept the cold comfort offered by the maxim "Mort saisit sans exception". ${ }^{2}$ Because they had never been able to control their destinies, the very thought of someday exercising such control was foreign to the poor at this time. Babies kept coming and children kept dying, prices went up, real wages went down, it was the way of the world, not to be questioned.

There is still more. In a society characterized by hereditary legal inequality, there are what we may call the ordinary discriminations, privileges having to do with taxation, justice, access to careers, precedence, etc., which, in theory at least, affect equally all persons not lucky enough to have been born noble. In reality, however, to be rich was a good thing, then no less than now. Money, if it could not buy honor - and it sometimes could and did just that - made the lack of it tolerable. The poor man lacked this resource. He lived with his family in a miserably furnished narrow little room devoid of material comfort. The single room and lone bed that often constituted his total patrimony completely deprived him of privacy, and even the sexual act became a public one. It is possible that he did not feel this deprivation, for privacy is very much a bourgeois value, and there is no evidence to show that the poor had accepted it. Still, this was not a state of things calculated to give the poor a sense of self-esteem.

When a poor man ventured out of his hovel, he came up against the dominant behavior patterns of society, to which he had not the means to conform, and his dignity suffered from this confrontation. His clothing was generally second hand and therefore out of fashion. The food he ate was limited in variety as it was in quantity. The lack of public transportation reenforced his sense of inferiority by making him conscious that could he only walk, while others rode. The places he went for entertainment, like the guinguettes in the

1 Jean Bourgeois Pichat, "Evolution générale de la population française depuis le XVIIIe siècle", in: Population, VI (1951), p. 658.

2 S. P. Hardy, Mes Loisirs, Bibliothèque Nationale, Ms. Fr. 6682, folio 152, 26 December 1775. 
suburbs where the drink was cheaper than in the city proper, were frequented by his own kind. And lest it be argued that the tendency of several social classes to live together in the same building was an effective counterweight to this kind of isolation, it should be pointed out that the anonymity of the urban apartment dweller, reenforced by vertical segregation, worked against any real mixing of the classes. Tenants might meet on the stairway, but their acquaintance probably stopped there. ${ }^{1}$ The poor man saw just enough of another kind of life to know that he was excluded from it.

Behind all this was a message the poor could not fail to perceive. They were different and condemned to remain so, not because they individually lacked character or personal qualities that would enable them to adapt to, and advance within, given situations, as the later theorists of Social Darwinism had it, but because they were born as a group to play a specific role, from which there was no escape. When, on a rare occasion, a poor man sought to establish himself in a role for which he was not thought to be suited, the barriers were raised in a more explicit manner. In 1781, the Parlement of Paris annulled the election of an agricultural day laborer as vestryman in the parish church of suburban Chaillot because "des gens d'une profession vile, ou des journaliers, qui gagnent leur vie par des moyens qui sont la preuve de leur indigence" were not eligible for this position. ${ }^{2}$

Even death did not put an end to the indignities to which the poor were subject. A funeral, of whatever class, appears to have been a costly affair, and attempts to raise the price might provoke the poor to display their anger. ${ }^{3}$ There was also the refusal of the clergy and pallbearers to do their duty, unless properly rewarded. In June, 1781, a poor parishoner of Saint Sulpice, having somehow come up with enough money to buy a coffin for his late wife, still lacked funds to pay the pallbearers. Service was refused him, and he had finally to employ six poor women to transport the body from his home to the church. This was the kind of thing to which the poor were particularly sensitive, for they were Christians and concerned about the welfare of their immortal souls, whether or not they were assiduous in their attendance at mass. They showed their annoyance at this particular incident by treating the local clergy, whom they held responsible for the pallbearers' loutish behavior, to a steady stream of abuse when they

${ }^{1}$ Cf. L. Caraccioli, Lettres d'un indien à Paris (Paris and Amsterdam, 1789), I, p. 256.

2 Abbé de Boyer, Principes sur l'administration temporelle des paroisses (Paris, 1786, two volumes), I, p. 32.

3 A. de Boislisle (ed.), Lettres de M. de Marville, Lieutenant général de Police au Ministre Maurepas (1742-1747) (Paris, 1896-1905, three volumes), I, p. 206. 
dared to appear in the streets at the head of another, presumably well paid, procession. ${ }^{1}$ The poor, who left little or no trace of their existence behind them, could not even be buried properly. If relatives or friends did not pay for the burial, their bodies were thrown into the common pits of the Cemetery of the Holy Innocents near the Halles, and not much care was taken to record their names. This was the ultimate indignity, a kind of deprivation of identity. ${ }^{2}$

Under these conditions, the poor had no alternative but to accept their situation, and this they did in a very particular way. Forced into misery by society, they reacted by seeking to make the best of that misery, rather than to do away with it. The poor turned inwards to form their own community with its own values and norms of behavior. The community was at once a cushion against the harsh realities of their daily lives and a barrier against full participation in the world at large. Although feelings of frustration no doubt remained quite strong at the individual level, the culture as a whole was characterized by the growth of a psychology of acceptance. And as that psychology was passed down across the generations from parents to children, it made it impossible for the group to develop self-esteem and class consciousness, and thereby to engage in political action. ${ }^{3}$

The first characteristic of the withdrawal from the larger community is the distrust and/or the reluctance to make use of certain major institutions. The hatred of hospitals by the poor is proverbial and was due not alone to the miserable conditions that prevailed there and to the fact that such a large percentage of those who entered never came out again. ${ }^{4}$ The hospital was also looked upon as a trap for the unfor-

${ }^{1}$ Hardy, Bibliothèque Nationale, Ms. Fr. 6683, folio 483.

2 Journal Encyclopédique, October, 1775, 183, cited in Bulletin de la Société de l'Histoire de Paris, XXXVIII (1911), pp. 297-298. The death certificate of a person buried at the expense of charity could not be signed by his relatives or friends. Information was gathered for the parish registers from gravediggers. This practice led to many abuses but ended only in 1775 by order of the police magistrates of the Châtelet.

${ }^{3}$ Acceptance may have had its rewards. Although thoroughly despised by the men of power, "le bon peuple de Paris" enjoyed a tacit freedom to get drunk and to engage in other amusements deemed worthy of the "canaille", to let off steam in ways not dangerous to society. But let them engage, as they occasionally did, in the smallest strike, bread riot or similar protest movement and all tolerance fell by the wayside.

4he literature on hospitals at the end of the eighteenth century is immense. I cite here only two: Rondonneau de la Motte, Essai historique sur l'Hôtel Dieu de Paris (Paris, 1787), notes that the sick and dying often lay together six to a bed. Abbé de Récalde, Traité sur les abus qui subsistent dans les hôpitaux (Saint Quentin and Paris, 1786) says that the Hôtel Dieu "est à présent redouté du dernier des hommes, par le trop grand nombre de pauvres que le malheur y rassemble". 
tunate poor, a kind of Malthusian instrument for keeping the population down. ${ }^{1}$ The mode of administration of charity was notably hardhearted outside as well as in the hospitals, and the poor resented it. How often they made their resentment known is another matter, but I know of at least one police ordonnance forbidding the poor "to injure and mistreat the Sisters of Charity of the parishes of Paris while receiving alms from them..."2

On the question of the poor man's attitude to the courts and the judicial system, our evidence is as yet very sparse. But the little we do have, in the form of interrogations of accused criminals, indicates a fear of authority, together with a strong penchant for litigation and the apparently contradictory tendency to apply to judicial or police officers for redress of even the most minor insults. ${ }^{3}$ But there can be no doubt as to the poor's lack of friendliness to the police, who were strongly suspected, not without reason, of persecuting the poor in order to fill their own pockets. It was common knowledge that Paris was full of police spies recruited from every walk of life. ${ }^{4} \mathrm{~A}$ bounty was paid for the capture of beggars, and this led to real abuses, much multiplied in the minds of poor men who did not regard beggary as a crime..$^{5}$ Any rumor concerning the police was readily accepted as true. In May, 1750, a report that police were kidnapping young boys, whose blood was to be used to bathe a princess suffering from a horrible disease, led to a series of riots in which several persons lost their lives. ${ }^{6}$

1 Anon., Un malade de l'Hôtel Dieu de Paris, aux âmes sensibles (Paris, 1787), passim, especially 13 :

"Quelle demeure affreuse! O honte! O ma Patrie!

Toi, dont l'humanité charme tout l'univers,

Vois ce triste cloaque où la Faux ennemie

Fait de vastes moissons depuis cinq cents hivers;

Maudissans les secours d'une charité dure,

Vois tous ces Malheureux, par milliers amassés.

Dans ce réduit infect, accusans la nature,

Et sur un seul grabat l'un sur l'autre entassés,

Respirans avec l'air le mélange funeste

Des poisons échappés au foyer de la peste."

2 Archives de la Seine, 6 AZ 133, 1 July 1718.

3 The interrogations and case histories of accused criminals are in the $Y$ series of the Archives Nationales. See also: Archives de la Préfecture de Police, AB 405 - in the quartier Saint Denis between 1779 and 1786 there were an enormous number of complaints over "insultes, mauvais propos, propos calomnieux". Most of the cases were settled by a simple apology or reprimand.

4 Hardy, Bibliothèque Nationale. Ms. Fr. 6681, folio 329, 3 May 1774; Marville, Lettres, I, pp. xvi-xvii.

${ }^{5}$ Hardy, Bibliothèque Nationale, Ms. Fr. 6683, folio 13, 3 July 1778.

- Mémoires de Jacques Louis Ménétra écrits par luy-même, Bibliothèque Historique de la Ville de Paris, Ms. 678, p. 13: [when he was a child] "dans cest 
One institution that escaped the fear and distrust bred by poverty was the Church, notwithstanding hatred of ecclesiastical functionaries and sharp reactions to the abuse of their authority. Although we may think of the poor as having been more superstitious than religious, they remained deeply attached to their own highly syncretic brand of Catholicism. This allegiance is not easily measured by the percentage of persons who went to mass on sundays or took communion at Easter, as the Canon Law required. I would attach very limited significance to the decrease in church attendance that may have taken place in our period. ${ }^{1}$ Nor would I think that the failure to regard Sunday as a day of rest indicated a state of creeping atheism, despite the fears of the royal government and the censure of English ladies raised in the sabbatarian tradition. ${ }^{2}$ The fact remains that the laboring poor believed in the community of saints, the use of the sacrements and the exercise of religious devotion. ${ }^{3}$ One reason for this is certainly the enormous availability of religion. There was always some church or other to which a visit would secure an indulgence. Special retreats for workers both male and female were held regularly. And of course

temps le bruit couroit que l'on prenoit les jeunne garson et que l'on les seigneoit et qu'il étoit perdue pour jamais et que de leur sangs servoit pour baigné une princesse ataquée d'une maladie quy ne pouvoit etre que guerit avec du sangs humain. Sela fit beaucoup de reumeurt dans Paris. Mon pere vint me cherchée à l'ecolle comme bien d'autre avec sept fort garson tonnelier quy portoit chacun un levier sur l'épaule. La rumeur fut si forte que les vitres des commissaire fure cassé et que l'on asomma plusieurs malheureux et meme que l'on en brula un en place de greve, que l'on avoit prie resemblant a un mouchard. L'on ne laissoit plus sortir les enfant. Il eu trois misérable quy fure penduë en place de greve pour faire justice et pour rendre le calme dans Paris." For the details of the affair, see Bibliothèque Nationale, Collection Joly de Fleury, 1101-1102 and Archives Nationales, X2b 1367-1368.

1 Gabriel Le Bras, Introduction à l'histoire de la pratique religieuse en France (Paris, 1942-1945, two volumes), I, pp. 98-99.

${ }^{2}$ See, for example, Archives Nationales, Y 13163 - Ordonnance de Police concernant l'observation des Dimanches et des Fêtes, 8 June 1764. This order was subsequently renewed many times. See also Piozzi, Observations, I, pp. 27-28; "And surely I never knew till now, that so little religion could exist in any Christian country as in this, where they drive their carts, and keep their little shops open on a Sunday, forbearing neither pleasure nor business, as I see, on account of observing that day upon which their Redeemer rose again. They have a tradition among the meaner people, that when Christ was crucified, he turned his head towards France, over which he pronounced his last blessing; but we must accuse them, if so, of being very ungrateful favourites."

3 This may have been particularly true of women, less so of men. Hardy notes a communion procession in St. Roch parish made up of fifty girls and a single boy but this is not sufficient evidence from which to draw conclusions. See Hardy, Bibliothèque Nationale, Ms. Fr. 6683, folio 275, 10 April 1780. 
there were the 29 obligatory holy days each year. ${ }^{1}$ Whatever the reason, the poor still relied on Catholicism for comfort and hope and protested bitterly when they thought they might be deprived of its ministrations. ${ }^{2}$

The Parisian poor, one might say, had a superstitious need to believe - what is of relatively little importance. This is not the place to detail all their vagaries, but the examples run the gamut from ghosts ${ }^{3}$ to elixirs of life and youth ${ }^{4}$ to faith healing. ${ }^{5}$ Such beliefs were not the monopoly of the poor. ${ }^{6}$ They carried credulity to extreme limits, because it gave them comfort and because they were not restrained by rigorous habits of thought. It was possible for them to believe a selfstyled prophetess, Dame Sainte Catherine, when she claimed in 1779 that she was to be the mother of the new messiah. ${ }^{7}$ And once again, that the wife of de Barentin, first president of the Cour des Aides, had given birth to "un abrisseau reconnu pour un groseiller quoique sans groseille, mais chargé... de cerises. Ce monstre d'une espèce toute nouvelle n'avoit rien de la forme humaine et étoit absolument inanimé. Cet accouchement singulier n'avoit pu que causer beaucoup de chagrin à toute la famille." 8

This credulity might trouble the enforcement of public order, but it was not likely to serve as a vehicle for revolutionary propaganda. Rumor, which is the handmaiden of belief, might lead to violence, but generally of the Church and King variety. That is clearly what the authorities had in mind when they ordered the arrest of a certain La Vallée d'Arancy in 1778. He had imagined the existence of a plot against the royal family. He lived in a house cocupied by 40 represen-

1 Almanach spirituel pour l'année M.D. CC. LXXIII (Paris, 1773), passim; Le Bras, Introduction, I, p. 41.

2 Bibliothèque Nationale, Collection Joly de Fleury, 1568. Sartine, Lieutenantgénéral de Police wrote to Joly de Fleury, Avocat-général du Parlement, on 24 March 1762: “. . . les habitants de la Paroisse St. Leu commencent à murmurer beaucoup sur le défaut de prêtres, nécessaires pour la desserte de cette église. . Quoique le service s'y fasse assés exactement, ils manquent néanmoins de confesseurs, et l'approche des fêtes de Paques rendra cette disette encore plus frapante."

${ }^{3}$ Hardy, Bibliothèque Nationale, Ms. Fr. 6680, folio 163-164, 9 December 1769; J. Colin de Plancy, Dictionnaire infernal (Brussels, 1845, fourth edition), p. 182. 4 P. A. Alletz, L'Albert moderne (Paris, 1768).

${ }^{5}$ Léon G. Pelissier (ed.), "Une lettre de Paris (1772)", in: Bulletin de la Société de l'Histoire de Paris, XXVI (1899), pp. 61-64.

- Dom Augustin Calmet, Dissertations sur les apparitions des Esprits (Paris, 1751, fourth edition), shows that belief in ghosts, vampires and associated phenomena was widespread.

7 Hardy, Bibliothèque Nationale, Ms. Fr. 6683 folio 139-140, 22 April 1779. Cf. the experience of Johanna Southcott in England a generation later.

${ }^{8}$ Hardy, Bibliothèque Nationale, Ms. Fr. 6682, folio 331, 27 February 1777. 
tatives of the "bas peuple", told his story to them, but was not thought by them to be crazy. The danger was evident. ${ }^{1}$

In the culture of poverty as it exists today, slum dwellers are aware of the socially dominant values, although they reject them as a code of behavior. This is what social workers, in their somewhat condescending vocabulary, call characteriological difficulties. Was this equally true in eighteenth century Paris, where communications were still in a primitive state and there were no mass media to be used for the purposes of manipulating public opinion?

On the one hand, as has already been shown, they did meet representatives of other classes in the course of their work, and the gossip mill may have - no doubt did - keep them abreast of what was going on in a limited portion of the outside world, the rest of the city and, just possibly, the rest of France. On the other hand, the poor were intensely parochial, often working, marrying and dying in the neighborhood where they were born. What I am suggesting here, without in any way being able to prove it, is that the community of which the domiciled poor were a part (and the floating poor as well, but only in so far as they carried their community with them by travelling in groups) guaranteed them a certain set of roots, a place in the shadow, if not in the sun. At the same time, that community protected its members by keeping them out of constant and direct contact with the pressures of the dominant culture. The poor man may thus have been spared some part of the personality conflict he would otherwise have experienced, had he known the full meaning of his inability to conform.

There is a great deal that we do not know - and may never know, given the state of the sources - about the culture of poverty in the eighteenth century, mainly those matters concerning personal habits and family organization. If we look once again at contemporary cultures, we are tempted to ask questions about, for example, marriage and the status of women, the place of the child and paternal authority. Was there a high rate of common law marriage, or did the prohibition of the Church serve as an effective counterweight to whatever temptations may have existed in this domain? Were there many illegitimate children ${ }^{2}$ Did the fact that a large number of women worked, along with their husbands, to support their families have a positive influence

1 Bibliothèque Nationale, Collection Joly de Fleury, 1292.

2 Peter Laslett. The World We Have Lost (London, 1966), Chapter six. The evidence we have about rural communities in both France and England indicates that there was not a great number of bastards, but we know little or nothing about the urban situation. 
on their status? Were children cherished, or did the fact that so many of them died so young and that those who survived were a burden on the limited resources of their parents diminish the value placed on children and childhood, as Ariès suggests. ${ }^{1}$ The large number of children abandoned to the Foundling Hospital - six to seven thousand a year in the 1770 s - indicates that he was right. ${ }^{2}$ And Restif de la Bretonne tells us that it was very common for young working men and women to live separately from their families. ${ }^{3}$ Firm conclusions on these matters will have to await the gathering of evidence, but it can be stated here and now that the answers are likely to vary among groups to be distinguished within the general category of the laboring poor. A gild artisan may very well have had a set of attitudes not shared by members of the floating population.

The reaction to insults already cited indicates that the poor shared a strong sense of honor. Honor and its defense may even have served as a surrogate for the material goods of which the poor were deprived. It is possible that as a poor man grew older and more certain that this situation would never change, he sought comfort in the demand for respect and esteem due his paternal authority. The example of many fathers of apparently modest circumstances who ask for a royal order to lock up an erring son in Bicêtre would give weight to this hypothesis. ${ }^{4}$ What actions were seen as constituting dishonorable behavior, and more specifically breeches of family honor, it is as yet impossible to say. The answer may well be: anything the father thought wrong. In any case, the makings of acute generational conflict are evident.

The Paris poor lived surrounded by violence. It was the socially approved violence of a society bases on principles of inequality, best symbolized by the Dickensian image of the driver running down those who dared to get in the way of his coach and four. It was also the socially disapproved violence of the professional criminal, with whom the poor lived at close quarters. But though they sometimes identified with criminals - they turned out in crowds to watch executions less on account of bloodthirstiness than out of sympathy for him who was about to die, and nothing made them happier than a last minute pardon $^{5}$ - they were not themselves notably violent. There was a great

1 Philippe Ariès, L'Enfant et la vie familiale sous l'ancien régime (Paris, 1960), translated as Centuries of Childhood (New York, 1962).

${ }^{2}$ Léon Lallemand, Histoire des enfants abandonnés et délaissés (Paris, 1885), p. 161 .

${ }^{3}$ Restif de la Bretonne, Les Nuits de Paris (London and Paris, 1788), III, p. 631. This separation may have been the result of special working conditions, rather than the desire to break away from the family.

4 Archives de la Préfecture de Police, AB 405.

5 Hardy, Bibliothèque Nationale, Ms. Fr. 6683, folio 229, 14 December 1779. 
deal of amateur crime, but it rarely involved physical harm to the victim. As the poor worked hard, so they swore hard and they played hard. In that sense their language was both violent and extremely pungent. ${ }^{1}$ When they went out for amusement, they tended to be loud and boisterous, whether dancing in the guinguettes at the Porcherons or staging a charivari - what middle western Americans call a chiveree under the windows of a newly married couple. ${ }^{2}$ They wanted instant gratification at the moment, and devil take the future. Why bother about a future that was likely to be as drab and uninviting as the present? So they drank on a Sunday until the money ran out; they quarrelled, fought, and made up when the sun went down. And the only dire result of all this was that some men did not show up for work on the Monday. ${ }^{3}$ I have no desire to paint a falsely idyllic picture, but it remains true that the poor were not depraved because they were deprived. ${ }^{4}$

The poor were set off from the rest of society by so many differences of clothing, diet, working and living conditions, not to mention language, $^{5}$ that they could not fail to develop some sense of themselves as belonging to a special community, that of the bottom dogs. They knew that they were different from, and less fortunate than, the nobles and bourgeois, no doubt lumped together in their minds in the single category of men one called Monsieur. This sense of difference, which takes into account only the most obvious phenomena of social life, is perfectly compatible with a sense of inferiority, a psychology of acceptance and deferential behavior in general, although it may as well serve to create feelings of suspicion and even contempt towards

1 André Charles Cailleau [d'après Barbier], Le Grouté des Porcherons (Paris, 1763); Anon., Code Poissard, ou Instruction comique et divertissante pour s'amuser pendant le carnaval (Paris, no date, but appears to be of the revolutionary period).

${ }^{2}$ Archives de la Seine, 6 AZ 133 - Sentence de Police contre plusieurs particuliers pour avoir fait charivari, 13 May 1735.

${ }^{3}$ [De Peysonnel,] Bibliothèque Nationale, Ms. Na. Fr. 3247; Vadé, La pipe cassée (Paris, 1755, third edition), p. 15 ; Cailleau, Gouté, p. 4.

4 For some cases of gross and altogether exceptional violence, see Hardy, Bibliothèque Nationale, Ms. Fr. 6683, folio 219, 21 November 1779 and folio 273, 3 April 1780 .

5 De Peysonnel, Les Numéros (Amsterdam, 1782, three volumes), II, pp. 118119: ". . . le jargon du peuple de Paris \& des environs, un monstre dégoutant composé de tous les barbarismes \& de tous les solécismes qu'il est possible de commettre dans la langue francaise." See also: Anon., Errors of Pronunciation \& Improper Expressions used frequently, and chiefly by the Inhabitants of London, to which is added, those in similar use, chiefly by the Inhabitants of Paris (London, 1817), where we are told that the Parisians have a distressing habit of saying "ben" for "bien" and of adding Zs in all sorts of unwonted places. 
those outside the group. It is very different from class consciousness which, by definition, involves an identification of the individual with an entity having positive attributes. Corrolary to class consciousness (as it develops amongst those deprived of power in a society) are notions of oppression and the need for change. The bourgeois of 1789 were class conscious, and thus were able to make a revolution. The laboring poor, by contrast, had not yet developed to the same point, hence they could, in the first instance, serve only as a force d'appoint. This should not surprise us. In a very real sense, this group consciousness corresponded to the social situation in which they found themselves. The laboring poor did not constitute a single class, but rather a melange of producers and merchants, skilled and unskilled, sedentary and nomadic. The positive identifications open to them, with a craft, a province or an occupational group, were always within the group, never encompassing the whole. They were divisive rather than unifying. Only later, with the coming of modern industrial society, were conditions for the development of a unitary class consciousness created.

This said, it should be remembered that the laboring poor were neither foolish nor blind. They were capable of resentment and anger, even of identifying the representatives of authority as the agents of their ills. We know the violence of their response to the pacte de famine and to bread shortages and high prices in general, to militia recruitment ${ }^{1}$ and police brutality. While in the main they blamed the king's ministers for their misfortunes, they could be driven to curse the monarch himself. At the death of Louis XV, a popular jingle was heard all over Paris:

"Cy gist Louis le fainéant

Qui donna papier en naissant

La guerre en grandissant

La famine en vieillissant

Et la peste en mourant."2

But this remained personal criticism, rather than a call for the destruction of the monarchy. When Louis XVI ascended the throne, he was acclaimed a worthy successor to King Henri IV of glorious memory - although one wit wrote:

1 Commandant Herlaut, Le recrutement de la Milice à Paris en 1743 (Coulommiers, 1921).

2 Hardy, Bibliothèque Nationale, Ms. Fr. 6681, folio 348, 20 May 1774. A slightly different and more elegant version appears in Emile Raunié (comp.), Chansonnier historique du XVIIIe siècle (Paris, 1883, ten volumes), VIII, p. 320 . 
“D’Henri ressuscité j'adopte le bon mot Mais pour me décider, j'attends la poule au pot."1

The poor were not capable of sustaining their anger, because they did not - could not - place it in a larger context.

I submit that they were incapable of thinking in larger terms, incapable of transforming their dislike for a man or set of men into a critique of society not only because they were poor, overworked, underfed, lacking education and opportunities, but because all of these disabilities had led them into the blind alley of the culture of poverty. Once there, they came to feel themselves helpless, dependent and inferior. They responded to pressures only in terms of that culture. They were caught in a vicious circle, and they could not break out until someone showed them the way. The idea that it was possible, not to say legitimate, to challenge the established order pointed out the direction to follow, and it was provided in 1789 by the revolutionary bourgeoisie. The bourgeois, however unconsciously, used the laboring poor as their shock troops, and the laboring poor, at least in part shaken out of their lethargy, soon began to pursue a program of their own. It was a program full of contradictions both in its means and its ends, and it would never be more than partially realized. It was, however, the beginning of a new struggle and a new tradition. At last the laboring poor had the chance to prove what Marivaux had said of them forty years earlier, that they were "beaucoup plus peuple et beaucoup moins canaille" than was generally believed.

1 Hardy, Bibliothèque Nationale, Ms. Fr. 6681, folio 361, 11 January 1774. 